\title{
DYSPNCEA IN CYANOTIC CONGENITAL HEART DISEASE
}

\author{
BY
}

\author{
HYWEL DAVIES AND NIKOS GAZETOPOULOS
}

From the Cardiac Department, Guy's Hospital, London

Received April 7, 1964

The role of chemical factors in the control of ventilation has been the subject of inquiry ever since Lavoisier at the end of the eighteenth century discovered that oxygen and carbon dioxide are intimately related to respiration. The effects, separately and together, of hypoxia, hypercapnia, and acidæmia have been investigated both in health and sickness.

In the commoner forms of heart disease where dyspnœa is prominent there are often disturbances of lung function due to the altered pressure-flow relation in the lungs, as for example in rheumatic valvular disease, left ventricular failure, or pulmonary hypertension. This makes it difficult to assess with confidence the respective contributions of lung damage on the one hand and chemical changes in the blood on the other in the causation of effort disability. When the pulmonary vascular bed is "protected" by the presence of pulmonary stenosis, however, the variable factor of lung damage associated with pulmonary hypertension is not present. It is then easier to assess the significance of non-pulmonary factors in the genesis of effort dyspnœa.

Shortness of breath on effort is usually considerable and is often severe in cyanotic congenital heart disease. Amongst a large number of patients with cardiac disease in whom we have studied the effects of exercise, there have been a number with morbus cæruleus. This report is concerned with the changes observed in these patients when they were actually dyspnœic.

\section{Patients AND Methods}

Twenty patients with cyanotic congenital heart disease have been studied, and of these 13 had Fallot's tetralogy, the severity ranging from acyanosis at rest in 6 , to a resting oxygen saturation of only 58 per cent in one. Four patients had the Eisenmenger syndrome as defined by Wood (1958), two of them with ventricular septal defect, one with ventricular septal defect and patent ductus arteriosus, and one with atrial septal defect. Two patients had pulmonary valve stenosis and atrial septal defect, and one had transposition of the great vessels with pulmonary stenosis. Details are given in Table I. In Cases 12, 16, and 17 Blalock anastomoses had been performed at the ages respectively of 10,11 , and 11 years; in the first two the shunt had become inadequate. Cases 3 and 9 underwent infundibular resection at the ages of 11 and 16 years, the former with great and lasting relief; in the latter case restenosis of the outflow tract of the right ventricle had occurred with reappearance of former symptoms.

For clarity of presentation the cases have been placed in three groups according to their resting arterial oxygen saturation. This appears to be a satisfactory arrangement since with few exceptions they fall into this pattern with respect to their clinical disability and the changes that we have observed on exercise. Group I consists of Cases 1-7, with a resting arterial oxygen saturation greater than 90 per cent. All fell within the designation of "acyanotic Fallot's tetralogy" except Case 7: this patient had an "Eisenmenger ASD". Group II consists of Cases 8-15, having a resting arterial oxygen saturation between 80 and 90 per cent (inclusive). Group III consists of Cases 16-20, with resting arterial oxygen saturations less than 80 per cent. 
TABLE I

Details of 20 Cases of Cyanotic Congenital Heart Disease

\begin{tabular}{|c|c|c|c|c|c|c|c|c|}
\hline \multicolumn{2}{|c|}{ Groups } & \multicolumn{2}{|c|}{$\begin{array}{l}\text { Case No., sex, } \\
\text { and age }\end{array}$} & \multirow{2}{*}{\begin{tabular}{l}
\multicolumn{1}{c}{ Diagnosis } \\
Fallot \\
Fallot \\
Fallot \\
Fallot \\
Fallot \\
Fallot \\
ASD Eis.
\end{tabular}} & \multirow{2}{*}{\begin{tabular}{|c}
$\begin{array}{c}\text { Resting } \\
\text { art. } \mathbf{O}_{2} \text { sat. } \\
(\%)\end{array}$ \\
97 \\
96 \\
93 \\
94 \\
95 \\
94 \\
97
\end{tabular}} & \multirow{2}{*}{$\begin{array}{c}\begin{array}{c}\mathrm{Hb} \\
\text { (g./100 ml.) }\end{array} \\
14 \cdot 7 \\
17 \cdot 8 \\
15 \cdot 6 \\
17 \cdot 3 \\
14 \cdot 5 \\
13 \cdot 4 \\
16 \cdot 5\end{array}$} & \multirow{2}{*}{$\begin{array}{c}\text { Disability } \\
\text { II } \\
\text { I } \\
\text { I } \\
\text { I } \\
\text { I } \\
\text { I } \\
\text { I }\end{array}$} & \multirow{2}{*}{$\begin{array}{c}\text { B.S.A. } \\
1.7 \\
1.9 \\
1.7 \\
1.7 \\
1.5 \\
1.5 \\
1.9\end{array}$} \\
\hline I. & .. & $\begin{array}{ll}1 & M \\
2 & M \\
3 & M \\
4 & M \\
5 & F \\
6 & F \\
7 & M\end{array}$ & $\begin{array}{l}38 \\
29 \\
19 \\
18 \\
18 \\
16 \\
35\end{array}$ & & & & & \\
\hline II . & .. & $\begin{array}{rl}8 & \mathrm{~F} \\
9 & \mathrm{~F} \\
10 & \mathrm{M} \\
11 & \mathrm{~F} \\
12 & \mathrm{~F} \\
13 & \mathrm{M} \\
14 & \mathrm{M} \\
15 & \mathrm{~F}\end{array}$ & $\begin{array}{l}41 \\
27 \\
34 \\
23 \\
26 \\
13 \\
25 \\
28\end{array}$ & $\begin{array}{l}\text { PS+ASD } \\
\text { Fallot } \\
\text { Fallot } \\
\text { Fallot } \\
\text { Fallot } \\
\text { Fallot } \\
\text { VSD Eis. } \\
\text { VSD+PDA Eis. }\end{array}$ & $\begin{array}{l}90 \\
90 \\
86 \\
87 \\
90 \\
90 \\
86 \\
84\end{array}$ & $\begin{array}{l}15 \cdot 0 \\
17 \cdot 8 \\
17 \cdot 0 \\
15 \cdot 3 \\
16 \cdot 4 \\
17 \cdot 2 \\
17 \cdot 8 \\
17 \cdot 7\end{array}$ & $\begin{array}{l}\text { II } \\
\text { II } \\
\text { II } \\
\text { II } \\
\text { I-II } \\
\text { I } \\
\text { II } \\
\text { II }\end{array}$ & $\begin{array}{l}1.6 \\
1.2 \\
1.7 \\
1.4 \\
1.7 \\
1.3 \\
1.7 \\
1.5\end{array}$ \\
\hline III . & . & $\begin{array}{ll}16 & \mathrm{M} \\
17 & \mathrm{M} \\
18 & \mathrm{~F} \\
19 & \mathrm{M} \\
20 & \mathrm{~F}\end{array}$ & $\begin{array}{l}23 \\
26 \\
23 \\
15 \\
26\end{array}$ & $\begin{array}{l}\text { Fallot } \\
\text { Fallot } \\
\text { VSD Eis. } \\
\text { Transpos.+ PS } \\
\text { PS+ASD }\end{array}$ & $\begin{array}{l}58 \\
75 \\
75 \\
54 \\
75\end{array}$ & $\begin{array}{l}22 \cdot 4 \\
19 \cdot 0 \\
17 \cdot 1 \\
24 \cdot 0 \\
21 \cdot 3\end{array}$ & $\begin{array}{l}\text { III } \\
\text { II } \\
\text { II-III } \\
\text { III } \\
\text { II }\end{array}$ & $\begin{array}{l}1.6 \\
1.6 \\
1.4 \\
1.4 \\
1.6\end{array}$ \\
\hline
\end{tabular}

The resting arterial oxygen saturation was measured immediately before bicycle or step exercise, except in Cases 8 , 9, and 20, where only catheter data are available. Disability grades according to New York Heart Association (1953). B.S.A. = Body surface area in square metres (DuBois and DuBois, 1915).

Exercise studies were originally performed during the course of cardiac catheterization, using a springloaded leg exerciser in the supine position. While this yielded data of considerable interest, it soon became apparent that the exercise level was too low to produce dyspnœa. Accordingly more strenuous forms of exercise, using standard step tests and the bicycle ergometer, were adopted.

For the cardiac catheterization all patients were premedicated, usually with Omnopon and scopolamine. Samples of blood for oxygen and metabolic studies were taken at rest and between the sixth and eighth minute of steady leg exercise, pulmonary and systemic flows being estimated by the Fick principle. The ventilation was measured from the spirometric tracing obtained after the fifth minute of exercise and corrected to BTPS.*

For the step and bicycle exercise the patient was not prepared in any way apart from the insistence that he should have been resting for the previous hour. The nomogram of Hugh-Jones and Lambert (1952) was used to estimate the exercise level on the steps, though this gives only a modest approximation of the work output at lower levels; the same can be said of the bicycle ergometer. Particular attention was paid to the maintenance of a steady level of exercise.

Under local analgesia a Cournand arterial needle was introduced into either the brachial or radial artery. After an interval of three minutes a resting blood sample was withdrawn, and measurements made of resting ventilation, oxygen uptake, and heart rate. The type of exercise was then commenced which was considered most appropriate to the case being studied, and continued until dyspnœa was present, as judged by the patient's statements and the evidence of considerable hyperventilation and tachypnœa. The level of effort chosen depended on the severity of the clinical disability; if after 10 minutes at the given level there was no dyspnœa, the exercise load was increased by $100-200 \mathrm{~kg}$. m./min. In a few cases the effects of walking before the other levels of effort were assessed.

Blood samples were withdrawn usually in the fourth and tenth minute of exercise at each level. Of the $10 \mathrm{ml}$. taken, $6 \mathrm{ml}$. were immediately transferred to test-tubes containing 6 per cent perchloric acid for lactate and pyruvate estimation by the methods respectively of Scholz et al. (1959) and the modification of the

* BTPS="Body conditions" for gas volumes (body temperature, ambient pressure, water vapour saturated at body temperature). 
Data Obtained During Cardiac Catheterization

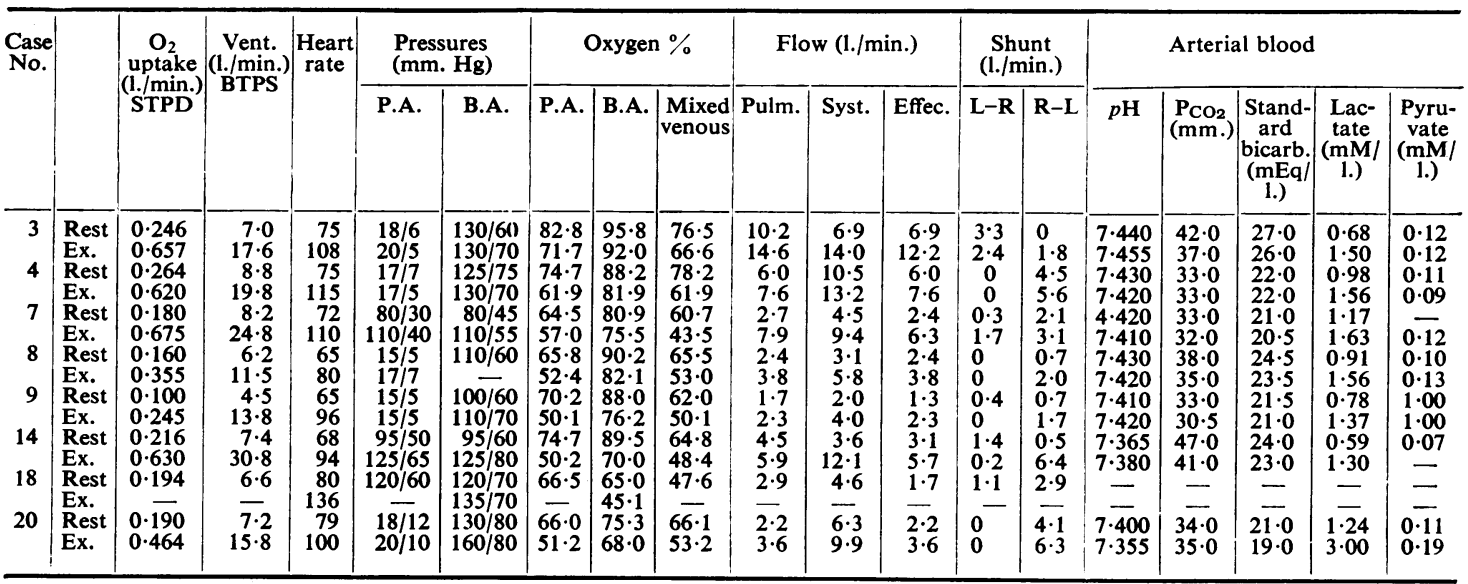

STPD = standard conditions for gas volumes.

BTPS $=$ body conditions for gas volumes.

P.A. = pulmonary artery.

B.A. = brachial artery.

Warburg technique as described by Landon, Fawcett, and Wynn (1962). The remainder of the blood sample was analysed for $p \mathrm{H}, \mathrm{P}_{\mathrm{CO}_{2}}$, and bicarbonate content by the micro-Astrup technique, applying the interpolation method of Andersen and Engel (1960). Oxygen saturation was measured in a Brinkman hæmoreflector. $\quad \mathrm{P}_{\mathrm{O}_{2}}$ was calculated from the nomogram of Severinghaus (1958).

It was intended to measure ventilation in all cases, but in the more disabled patients interference with respiration by the mouthpiece made this unsafe at higher ventilatory levels. Where measurements were made, a Wright anemometer was used and the expired air was collected in a Douglas Bag for analysis by the Haldane method. The ventilation was measured between the fifth and tenth minute of each exercise level. When measurements of ventilation were not made dyspnœa was assessed on a clinical basis as severe (Grade III), moderate (Grade II), or mild (Grade I).

There were no untoward effects from these tests apart from feelings of nausea either during or after the exercise in a few cases. It is stressed that during such studies the patient must be watched carefully at all times and the exercise terminated as soon as there are any signs of distress. This is particularly so in the Fallot group, where severe dyspnœa may appear very quickly after a period of apparent comfort at the same exercise level.

Where necessary, information derived from the study of other patients in this laboratory over the past five years has been drawn upon.

\section{RESULTS}

The data obtained are presented in Tables II and III. Table II shows the results of exercise during cardiac catheterization, and Table III those at bicycle, step, or walking exercise.

Figure 1 summarizes the changes in the main factors studied at higher exercise levels where dyspnœa was present.

Arterial Oxygen. (a) At rest. This depended on the nature and severity of the lesion. In 4 out of 5 cases in whom arterial oxygen estimations were made both during cardiac catheterization and before bicycle or step tests there were differences in the resting saturations on the two occasions. The values at catheterization were lower in three cases, by 10 per cent in Case 7, 16 per cent in Case 18, and 6 per cent in Case 4; Case 3 showed no difference, while Case 14 had a slightly higher level at catheterization.

(b) During exercise. The arterial oxygen saturation fell in all cases. At catheterization the fall was modest; during bicycle or step exercise very low values were seen at times, e.g. 25 per cent in 
TABLE III

Data Obtained During Step and Bicycle Exercise

\begin{tabular}{|c|c|c|c|c|c|c|c|c|c|c|c|c|c|c|c|}
\hline \multirow{2}{*}{$\begin{array}{l}\text { Case } \\
\text { No. }\end{array}$} & \multirow[t]{2}{*}{ State } & \multirow{2}{*}{$\frac{\text { Work }}{\left(\begin{array}{c}\text { kg.m. } / \text { min.) } \\
\text { I }\end{array}\right.}$} & \multirow{2}{*}{$\frac{\begin{array}{c}\text { Dura- } \\
\text { tion }\end{array}}{\text { (min.) }}$} & \multirow{2}{*}{$\begin{array}{c}\text { Vent. } \\
\text { (1./min.) } \\
\text { BTPS }\end{array}$} & \multirow{2}{*}{$\mid \begin{array}{c}\mathrm{O}_{2} \\
\text { uptake } \\
\text { (1./min.) } \\
\text { STPD }\end{array}$} & \multirow{2}{*}{$\begin{array}{c}\text { Heart } \\
\text { rate }\end{array}$} & \multirow{2}{*}{$\begin{array}{c}\text { Dyspncea } \\
\text { grade }\end{array}$} & \multicolumn{8}{|c|}{ Arterial blood } \\
\hline & & & & & & & & $\begin{array}{l}\mathrm{O}_{2} \\
\%\end{array}$ & $p \mathbf{H}$ & $\begin{array}{l}\mathrm{Po}_{2} \\
\left(\mathrm{~mm}_{\text {.) }}\right) \\
\text { (calcu- } \\
\text { lated) }\end{array}$ & \begin{tabular}{|c|}
$\mathrm{PCO}_{2}$ \\
$(\mathrm{~mm})$.
\end{tabular} & $\begin{array}{c}\text { Standard } \\
\text { bicarb. } \\
\text { (mEq/1.) }\end{array}$ & $\begin{array}{l}\text { Lactate } \\
(\mathrm{mM} / \mathrm{l} .)\end{array}$ & \begin{tabular}{|l|} 
Pyruvate \\
(mM/l.)
\end{tabular} & $L / P$ \\
\hline \multirow[t]{3}{*}{1} & Rest & & & $9 \cdot 25$ & & 84 & (Group & I) & $7 \cdot 440$ & 96 & 33.0 & 23.5 & 1.04 & 0.12 & 8.6 \\
\hline & Ex. steps & 400 & $\begin{array}{l}4 \\
7\end{array}$ & $34 \cdot 0$ & & $\begin{array}{l}120 \\
130\end{array}$ & II & $\begin{array}{l}63 \\
60\end{array}$ & $\begin{array}{l}7 \cdot 410 \\
7 \cdot 405\end{array}$ & 32 & $\begin{array}{l}35.0 \\
34.0\end{array}$ & $\begin{array}{l}22.0 \\
21.0\end{array}$ & $\begin{array}{l}2 \cdot 73 \\
3 \cdot 44\end{array}$ & $\begin{array}{l}0.15 \\
0.15\end{array}$ & $\begin{array}{r}18 \cdot 2 \\
23 \cdot 0\end{array}$ \\
\hline & Recovery & & $\begin{array}{r}5 \\
10\end{array}$ & $24 \cdot 0$ & & & & $\begin{array}{l}79 \\
88\end{array}$ & $\begin{array}{l}7 \cdot 420 \\
7 \cdot 445\end{array}$ & $\begin{array}{l}43 \\
55\end{array}$ & $\begin{array}{l}29 \cdot 0 \\
31 \cdot 0\end{array}$ & $\begin{array}{l}20 \cdot 5 \\
22 \cdot 5\end{array}$ & $\begin{array}{l}3.0 \\
1.82\end{array}$ & $\begin{array}{l}0 \cdot 18 \\
0 \cdot 11\end{array}$ & $\begin{array}{l}16.7 \\
16.5\end{array}$ \\
\hline \multirow[t]{2}{*}{2} & Rest & & & $7 \cdot 6$ & & & 0 & $\overline{96}$ & $7 \cdot 452$ & 84 & $36 \cdot 0$ & $25 \cdot 0$ & 0.83 & $0 \cdot 10$ & $8 \cdot 3$ \\
\hline & Ex. steps & 400 & $\begin{array}{r}3 \\
10\end{array}$ & 28.0 & & & $\begin{array}{l}\text { I } \\
\text { II }\end{array}$ & $\begin{array}{l}87 \\
80\end{array}$ & $\begin{array}{l}7 \cdot 405 \\
7 \cdot 395\end{array}$ & 45 & $\begin{array}{l}38 \cdot 0 \\
33 \cdot 0\end{array}$ & $\begin{array}{l}23 \cdot 5 \\
21 \cdot 0\end{array}$ & $\begin{array}{l}3 \cdot 51 \\
4 \cdot 75\end{array}$ & $\begin{array}{l}0 \cdot 12 \\
0 \cdot 18\end{array}$ & $\begin{array}{l}29 \cdot 2 \\
26 \cdot 4\end{array}$ \\
\hline \multirow[t]{3}{*}{3} & Rest & & & $7 \cdot 6$ & & 92 & 0 & $\overline{93}$ & $7 \cdot 455$ & 67 & $34 \cdot 0$ & $25 \cdot 0$ & 0.91 & $0 \cdot 10$ & $9 \cdot 1$ \\
\hline & Ex. cycle & 300 & $\begin{array}{r}3 \\
7 \\
17\end{array}$ & $21 \cdot 4$ & 1.07 & $\begin{array}{l}110 \\
120 \\
120\end{array}$ & $\begin{array}{l}\text { I } \\
\text { I } \\
\text { I }\end{array}$ & $\begin{array}{l}86 \\
85 \\
81\end{array}$ & $\begin{array}{l}7.455 \\
7.460 \\
7.465\end{array}$ & $\begin{array}{l}50 \\
49 \\
45\end{array}$ & $\begin{array}{l}36.0 \\
30.0 \\
36.0\end{array}$ & $\begin{array}{l}25.0 \\
23.0 \\
26.0\end{array}$ & $\begin{array}{l}1.24 \\
1.30 \\
0.91\end{array}$ & $\begin{array}{l}0 \cdot 12 \\
0 \cdot 14 \\
0 \cdot 12\end{array}$ & $\begin{array}{r}10 \cdot 3 \\
9 \cdot 3 \\
7 \cdot 6\end{array}$ \\
\hline & cycle & 500 & 3 & $45 \cdot 0$ & $1 \cdot 34$ & 160 & II & 73 & $7 \cdot 460$ & 37 & $30 \cdot 0$ & $24 \cdot 0$ & $1 \cdot 36$ & $0 \cdot 12$ & $11 \cdot 3$ \\
\hline \multirow[t]{5}{*}{4} & Rest & & & 6.5 & & 82 & 0 & $\overline{94}$ & $7 \cdot 420$ & 72 & $27 \cdot 0$ & $19 \cdot 0$ & 1.04 & $0 \cdot 10$ & $10 \cdot 4$ \\
\hline & Ex. walking & 200 & 10 & $18 \cdot 2$ & 0.58 & 100 & 0 & 78 & $7 \cdot 420$ & 42 & $28 \cdot 0$ & $20 \cdot 0$ & $1 \cdot 17$ & 0.09 & 13.0 \\
\hline & cycle & 300 & $\begin{array}{r}4 \\
10\end{array}$ & $25 \cdot 6$ & 0.83 & $\begin{array}{l}120 \\
126\end{array}$ & I & $\begin{array}{l}69 \\
56\end{array}$ & $\begin{array}{l}7 \cdot 410 \\
7 \cdot 420\end{array}$ & $\begin{array}{l}36 \\
28\end{array}$ & $\begin{array}{l}31 \cdot 0 \\
31 \cdot 0\end{array}$ & $\begin{array}{l}20.5 \\
21 \cdot 0\end{array}$ & $\begin{array}{l}2.53 \\
2.73\end{array}$ & $\begin{array}{l}0 \cdot 10 \\
0 \cdot 17\end{array}$ & $\begin{array}{l}25.3 \\
16.0\end{array}$ \\
\hline & cycle & 400 & $\begin{array}{r}4 \\
10\end{array}$ & $40 \cdot 2$ & $1 \cdot 160$ & $\begin{array}{l}160 \\
164\end{array}$ & II & $\begin{array}{l}50 \\
47\end{array}$ & $\begin{array}{l}7 \cdot 395 \\
7 \cdot 375\end{array}$ & $\begin{array}{l}26 \\
26\end{array}$ & $\begin{array}{l}33.0 \\
23.0\end{array}$ & $\begin{array}{l}20 \cdot 5 \\
18 \cdot 5\end{array}$ & $\begin{array}{l}3 \cdot 18 \\
4 \cdot 42\end{array}$ & $\begin{array}{l}0.17 \\
0.19\end{array}$ & $\begin{array}{l}18 \cdot 7 \\
23 \cdot 3\end{array}$ \\
\hline & Recovery & & 10 & & & 104 & & 86 & $7 \cdot 400$ & 54 & 28.0 & $18 \cdot 5$ & - & - & - \\
\hline \multirow[t]{4}{*}{5} & Rest & & & $4 \cdot 3$ & $0 \cdot 11$ & 76 & 0 & $\overline{95}$ & $7 \cdot 480$ & 74 & 33.5 & $25 \cdot 7$ & 0.55 & 0.07 & 7.9 \\
\hline & Ex. cycle & 200 & $\begin{array}{r}4 \\
10\end{array}$ & $11 \cdot 3$ & 0.38 & $\begin{array}{l}135 \\
140\end{array}$ & I & $\begin{array}{l}89 \\
83\end{array}$ & $\begin{array}{l}7 \cdot 445 \\
7 \cdot 450\end{array}$ & $\begin{array}{l}56 \\
51\end{array}$ & $\begin{array}{l}33 \cdot 2 \\
30 \cdot 5\end{array}$ & $\begin{array}{l}24 \cdot 5 \\
23 \cdot 0\end{array}$ & $\begin{array}{l}1.69 \\
2.08\end{array}$ & 0.09 & $18 \cdot 8$ \\
\hline & cycle & 400 & $\begin{array}{r}4 \\
10\end{array}$ & 25.8 & 1.03 & $\begin{array}{l}160 \\
160\end{array}$ & II & $\begin{array}{l}80 \\
81\end{array}$ & $\begin{array}{l}7 \cdot 410 \\
7 \cdot 395\end{array}$ & $\begin{array}{l}45 \\
46\end{array}$ & $\begin{array}{l}32 \cdot 2 \\
30 \cdot 5\end{array}$ & $\begin{array}{l}22.0 \\
20 \cdot 5\end{array}$ & $\begin{array}{l}3.90 \\
3.84\end{array}$ & $\begin{array}{l}0.12 \\
0.13 \\
0.17\end{array}$ & $\begin{array}{l}17 \cdot 3 \\
30 \cdot 0 \\
22 \cdot 6\end{array}$ \\
\hline & Recovery & & $\begin{array}{r}5 \\
10\end{array}$ & $\begin{array}{l}8 \cdot 2 \\
5 \cdot 0\end{array}$ & & 100 & & 94 & $\begin{array}{l}7.395 \\
7.425\end{array}$ & 73 & $\begin{array}{l}32 \cdot 5 \\
28.0\end{array}$ & $\begin{array}{l}21.0 \\
21.0\end{array}$ & $\begin{array}{l}2.99 \\
2 \cdot 40\end{array}$ & $\begin{array}{l}0 \cdot 18 \\
0 \cdot 17\end{array}$ & $\begin{array}{l}16 \cdot 6 \\
14 \cdot 1\end{array}$ \\
\hline \multirow[t]{5}{*}{6} & Rest & & & 6.0 & & 84 & 0 & 9 & $7 \cdot 505$ & 65 & $28 \cdot 0$ & $23 \cdot 0$ & 0.72 & 0.08 & $9 \cdot 0$ \\
\hline & Ex. walking & 200 & 6 & $13 \cdot 5$ & 0.58 & 96 & 0 & 93 & $7 \cdot 495$ & 64 & $29 \cdot 0$ & $23 \cdot 0$ & 0.85 & 0.07 & $12 \cdot 1$ \\
\hline & cycle & 300 & $\begin{array}{r}3 \\
9 \\
12\end{array}$ & $19 \cdot 7$ & 0.87 & $\begin{array}{l}120 \\
132 \\
130\end{array}$ & $\begin{array}{l}\text { I } \\
\text { I } \\
\text { I }\end{array}$ & $\begin{array}{l}88 \\
69 \\
68\end{array}$ & $\begin{array}{l}7 \cdot 435 \\
7 \cdot 390 \\
7 \cdot 440\end{array}$ & $\begin{array}{l}55 \\
37 \\
34\end{array}$ & $\begin{array}{l}30 \cdot 0 \\
36 \cdot 0 \\
33 \cdot 0\end{array}$ & $\begin{array}{l}20 \cdot 5 \\
20 \cdot 5 \\
21 \cdot 4\end{array}$ & $\begin{array}{l}1 \cdot 82 \\
2 \cdot 40 \\
2 \cdot 40\end{array}$ & $\begin{array}{l}0.15 \\
0.15 \\
0 \cdot 16\end{array}$ & $\begin{array}{l}12.1 \\
16.0 \\
15.0\end{array}$ \\
\hline & cycle & 400 & 4 & & & 150 & II & 51 & $7 \cdot 410$ & 26 & $36 \cdot 0$ & $21 \cdot 4$ & $2 \cdot 34$ & $0 \cdot 16$ & $14 \cdot 6$ \\
\hline & Recovery & & 5 & & & 84 & 0 & 72 & $7 \cdot 435$ & 37 & $33 \cdot 0$ & $20 \cdot 5$ & $2 \cdot 15$ & 0.22 & 9.8 \\
\hline \multirow[t]{4}{*}{7} & Rest & & & $10 \cdot 2$ & $0 \cdot 36$ & 80 & 0 & 97 & $7 \cdot 485$ & 91 & $27 \cdot 0$ & $22 \cdot 0$ & 1.82 & $0 \cdot 13$ & $14 \cdot 0$ \\
\hline & Ex. cycle & 400 & 4 & 38.0 & 1.24 & 120 & I & 81 & $7 \cdot 454$ & 44 & $29 \cdot 0$ & $21 \cdot 0$ & $2 \cdot 67$ & - & - \\
\hline & cycle & 600 & $\begin{array}{r}10 \\
3\end{array}$ & & & $\begin{array}{l}136 \\
160\end{array}$ & II & $\begin{array}{l}70 \\
66\end{array}$ & $\begin{array}{l}7 \cdot 390 \\
7 \cdot 400\end{array}$ & $\begin{array}{l}37 \\
\mathbf{3 4}\end{array}$ & $\begin{array}{l}32.0 \\
31.0\end{array}$ & $\begin{array}{l}19.0 \\
19.0\end{array}$ & $\begin{array}{l}3 \cdot 64 \\
4 \cdot 29\end{array}$ & $\underline{0.18}$ & $20 \cdot 2$ \\
\hline & Recovery & & $\begin{array}{r}5 \\
10\end{array}$ & & & $\begin{array}{l}96 \\
98\end{array}$ & $\begin{array}{l}0 \\
0\end{array}$ & $\begin{array}{l}97 \\
98\end{array}$ & $\begin{array}{l}7.420 \\
7.510\end{array}$ & $\begin{array}{l}98 \\
99\end{array}$ & $\begin{array}{l}26 \cdot 0 \\
22 \cdot 0\end{array}$ & $\begin{array}{l}19.0 \\
22.0\end{array}$ & $\begin{array}{l}3.38 \\
1.82\end{array}$ & 二 & 二 \\
\hline
\end{tabular}

Table III continued overleaf. 
TABLE III cont'd.

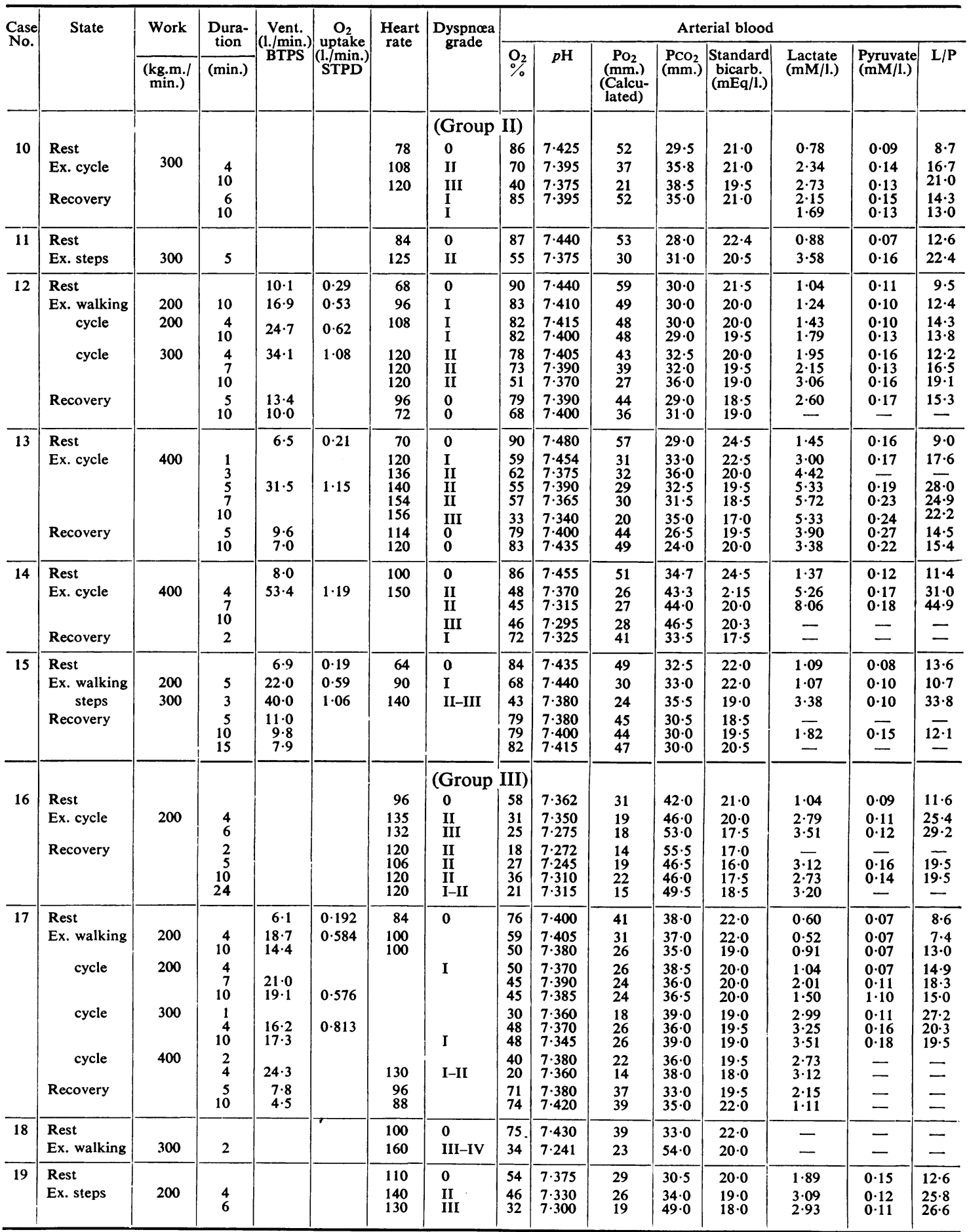

BTPS. STPD. $\quad \mathrm{L} / \mathrm{P}=$ Lactate/pyruvate ratio. 
TABLE IV

\begin{tabular}{|c|c|c|c|c|c|c|c|c|c|c|c|c|c|c|c|c|c|}
\hline Case No. & 1 & 2 & 3 & 4 & 5 & 6 & 7 & 10 & 11 & 12 & 13 & 14 & 15 & 16 & 17 & 18 & 19 \\
\hline $\begin{array}{l}\text { Rest arterial } \mathbf{O}_{2} \% \\
\text { Rest arterial } \mathbf{P}_{\mathrm{O}_{2}}(\mathrm{~mm} .)\end{array}$ & $\begin{array}{l}97 \\
95\end{array}$ & $\begin{array}{l}96 \\
85\end{array}$ & $\begin{array}{l}93 \\
67\end{array}$ & $\begin{array}{l}94 \\
73\end{array}$ & $\begin{array}{l}95 \\
74\end{array}$ & $\begin{array}{l}94 \\
65\end{array}$ & $\begin{array}{l}97 \\
91\end{array}$ & $\begin{array}{l}86 \\
52\end{array}$ & $\begin{array}{l}87 \\
53\end{array}$ & $\begin{array}{l}90 \\
59\end{array}$ & $\begin{array}{l}90 \\
57\end{array}$ & $\begin{array}{l}86 \\
51\end{array}$ & $\begin{array}{l}84 \\
49\end{array}$ & $\begin{array}{l}58 \\
31\end{array}$ & $\begin{array}{l}76 \\
41\end{array}$ & $\begin{array}{l}75 \\
39\end{array}$ & $\begin{array}{l}54 \\
29\end{array}$ \\
\hline $\begin{array}{l}\text { Exercise arterial } \mathbf{O}_{2} \% \\
\text { Exercise arterial } \mathbf{P}_{\mathrm{O}_{2}}(\mathrm{~mm} .)\end{array}$ & $\begin{array}{l}60 \\
31\end{array}$ & $\begin{array}{l}80 \\
45\end{array}$ & $\begin{array}{l}81 \\
37\end{array}$ & $\begin{array}{l}47 \\
26\end{array}$ & $\begin{array}{l}81 \\
46\end{array}$ & $\begin{array}{l}51 \\
27\end{array}$ & $\begin{array}{l}66 \\
34\end{array}$ & $\begin{array}{l}40 \\
21\end{array}$ & $\begin{array}{l}55 \\
30\end{array}$ & $\begin{array}{l}51 \\
27\end{array}$ & $\begin{array}{l}33 \\
20\end{array}$ & $\begin{array}{l}46 \\
28\end{array}$ & $\begin{array}{l}43 \\
24\end{array}$ & $\begin{array}{l}25 \\
18\end{array}$ & $\begin{array}{l}20 \\
14\end{array}$ & $\begin{array}{l}34 \\
23\end{array}$ & $\begin{array}{l}32 \\
21\end{array}$ \\
\hline
\end{tabular}

Arterial $\mathrm{O}_{2}$ saturation and partial pressure at rest and at peak of exercise in subjects exercised to point of dyspnœa.

Case 16 and 20 per cent in Case 17. Table IV shows the saturations and partial pressures of oxygen that were found in the arterial blood at the peak of exercise, which represents in almost all cases the point at which it had to be terminated.

The lowest saturation seen was 18 per cent in Case 16 , Corresponding to a $\mathrm{P}_{\mathrm{O}_{2}}$ of $14 \mathrm{~mm}$. (Table III). This occurred shortly after the cessation of exercise. Symptoms varied considerably in relation to the level of arterial oxygen, from Cases 1 and 2 who were incommoded when their saturations were 60 and 80 per cent respectively, to Case 17 who was content to carry on when his arterial oxygen saturation was 20 per cent. Clearly the oxygen saturation is not the only factor that determines disability.

Figure 2 shows the fall in partial pressure of arterial oxygen on exercise as a function of its resting value. It enables us to derive an approximate estimate of the level that might be attained during exercise leading to dyspnœa in any cyanosed patient whose resting level is known. For example, if the resting saturation were 80 per cent $\left(\mathrm{P}_{\mathrm{O}_{2}}\right.$ of $45 \mathrm{~mm}$. at $\left.p \mathrm{H} \mathrm{7.4}\right)$, the exercise value would be likely to fall to around 35-40 per cent $\left(\mathrm{P}_{\mathrm{O}_{2}}\right.$ of about $22 \mathrm{~mm}$. at $p \mathrm{H} \mathrm{7 \cdot 3)}$ before dyspnœa would prevent the patient from exercising any further.

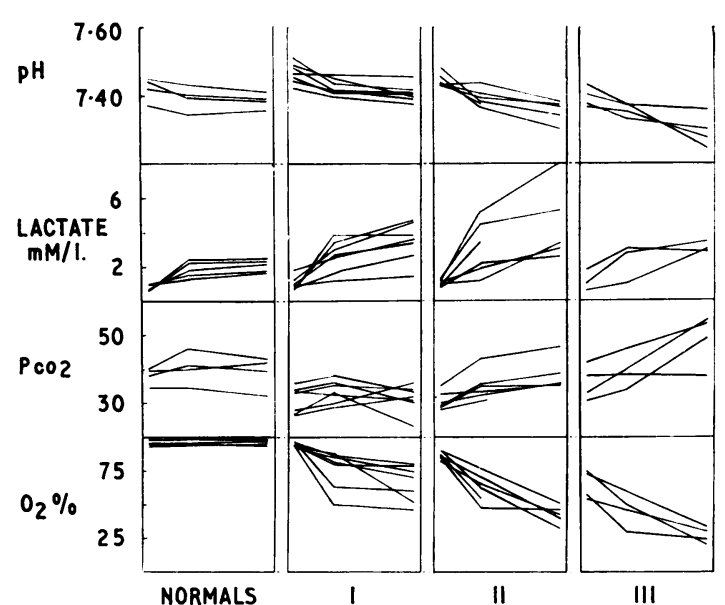

FIG. 1.-Changes in arterial oxygen saturation, $\mathbf{P}_{\mathrm{CO}_{2}}$, lactate, and $p \mathrm{H}$ on exercise in normal subjects and three groups of patients with cyanotic congenital heart disease. Group I, resting arterial oxygen saturation above 90 per cent; Group II, 80-90 per cent; Group III, below 80 per cent. The first point represents the resting value, the second that after approximately three minutes of exercise, and the third that at the highest level of exercise when dyspnœa was present.

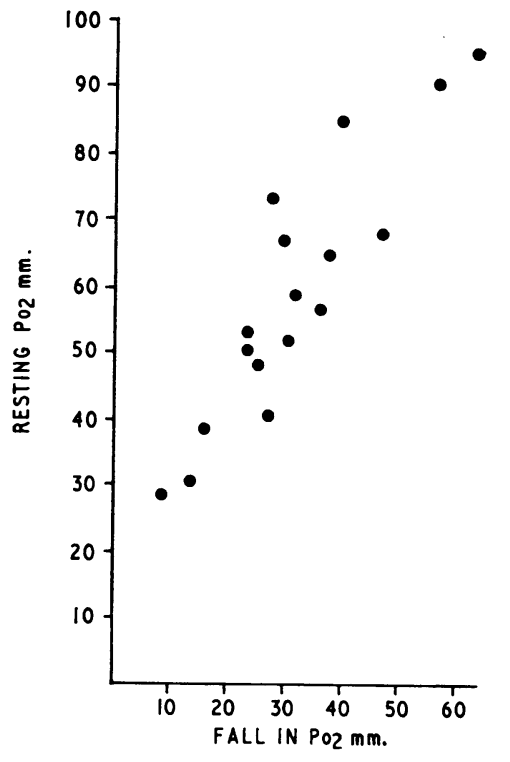

Fig. 2.-The relation between the resting arterial $\mathrm{P}_{\mathrm{O}_{2}}$ and the fall below that value which occurred when exercise was continued to the point of dyspnca. 
The average arterial $\mathrm{P}_{\mathrm{O}_{2}}$ on effort in Group I was $35 \mathrm{~mm} . \mathrm{Hg}$, in Group II $25 \mathrm{~mm} . \mathrm{Hg}$, and in Group III $22 \mathrm{~mm}$. $\mathrm{Hg}$, the resting values being 79, 54, and $35 \mathrm{~mm}$. $\mathrm{Hg}$ respectively. There was thus a fall of $44 \mathrm{~mm}$. in Group I, $29 \mathrm{~mm}$. in Group II, and $13 \mathrm{~mm}$. in Group III.

On cessation of exercise, the rise in arterial saturation was usually prompt. In Case 16, however, the level continued to fall for several minutes before rising again. Eight minutes later it fell once more (Table III). Both these episodes were accompanied by manifestations of excessive vagal activity, viz. nausea, sweating, and bradycardia.

Arterial $P_{\mathrm{CO}_{2}}$. (a) At rest. At cardiac catheterization the values were very variable, ranging from $33 \mathrm{~mm}$. in Cases 4, 7, and 9, to 38 and $42 \mathrm{~mm}$. in Cases 8, and 3, to $47 \mathrm{~mm}$. in Case 14 .

Before the bicycle or step tests the circumstances were very different in that the patients were not sedated and there was necessarily a measure of anxiety accompanying the insertion of the arterial needle, the measurement of ventilation, etc. The $\mathrm{P}_{\mathrm{CO}_{2}}$ values found in the patients, as in those of Campbell, Hunt, and Poulton (1923), were lower than those usually seen under similar conditions in normal subjects and in others without central cyanosis. It would be tempting to relate this to the fact that there is in most of them a lowered arterial oxygen tension, since hypoxæmia has been so widely held to be responsible for hyperventilation and consequent hypocapnia (Morse and Cassels, 1953). However, on examining the relation of the arterial oxygen to the $\mathrm{CO}_{2}$ levels, it is clear that the more cyanosed patients do not in fact have the lower values of $\mathbf{P}_{\mathrm{CO}_{2}}$ (Table III and Fig. 3). All that can be said is that the cyanosed patients had on the whole a lower arterial $\mathbf{P}_{\mathrm{CO}_{2}}$ than normal, but that the lowering was not proportional to the degree of hypoxæmia.

The finding of a lower-than-normal arterial $\mathrm{P}_{\mathrm{CO}_{2}}$ in a patient with a right-to-left shunt must mean that the pulmonary venous $\mathrm{P}_{\mathrm{CO}_{2}}$ is particularly low. This was measured during cardiac catheterization in Case 20, with severe pulmonary stenosis and reversed inter-atrial shunt, and shown to be $26 \mathrm{~mm}$. Hg. Gootman, Scarpelli, and Rudolph (1963) have recorded the pulmonary venous $\mathbf{P}_{\mathrm{CO}_{2}}$ in hypoxic patients and found it to be low $(18-27 \mathrm{~mm}$. $\mathrm{Hg}$ ).

(b) On exercise. The behaviour of the arterial $\mathrm{P}_{\mathrm{CO}_{2}}$ during exercise was significantly different in the three groups (Fig. 1 and Table III). In Group I, the acyanotic group, the level rose initially and then fell below the resting value. In Group III, the most cyanosed, there was a progressive rise in $\mathrm{P}_{\mathrm{CO}_{2}}$, uninterrupted by any fall. In Group II the pattern of change was intermediate between that of the other two groups.

Campbell (1934) found a diminished output of carbon dioxide in the early minutes of exercise in patients with heart disease. Davison, Armitage, and Arnott (1953) found a delay in the ventilatory response in the early minutes of exercise in patients with cyanotic congenital heart disease, and noted that there must be considerable retention of $\mathrm{CO}_{2}$ at this time. We have confirmed an

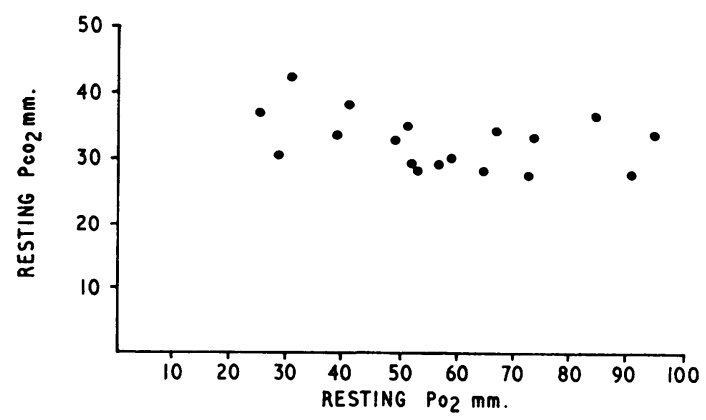

FIG. 3.-The resting $\mathrm{P}_{\mathrm{CO}_{2}}$ in relation to the degree of arterial hypoxæmia.

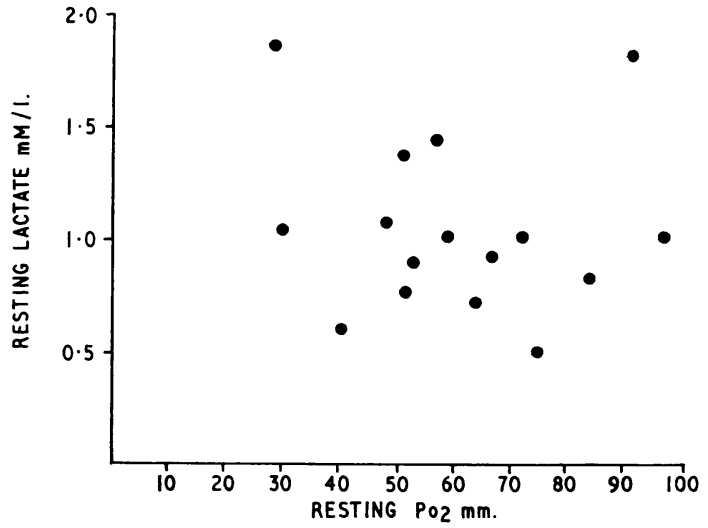

FIG. 4.-The resting arterial lactate concentrations related to $\mathrm{PO}_{2}$. 


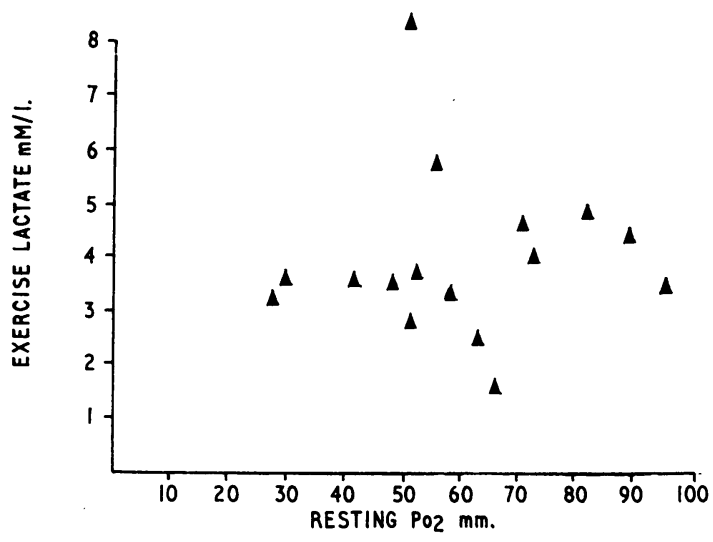

Fig. 5.-The exercise arterial lactate concentration related to the resting $\mathrm{P}_{2}$.

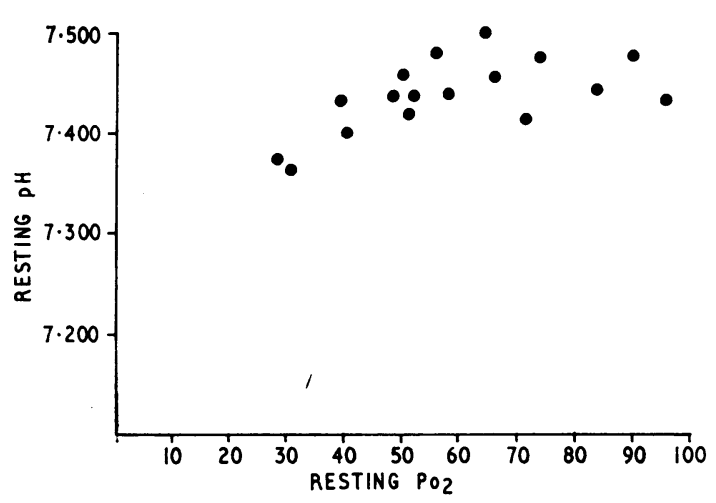

Fig. 6.-The $p \mathrm{H}$ and $\mathrm{P}_{\mathrm{O}_{2}}$ in the arterial blood at rest.

early rise of arterial $\mathrm{P}_{\mathrm{CO}_{2}}$, but must note that it occurred not only in cyanosed patients but also in normal subjects (Rahn and Otis, 1949; Suskind et al., 1950; Matell, 1963).

Arterial Lactate and Pyruvate Concentration. (a) At rest. These were on the whole within the normal range, confirming the findings of Hallock (1939) and Havel and Watkins (1950). Fig. 4 shows that there is no relation between the actual level of $\mathbf{P}_{\mathrm{O}_{2}}$ and arterial lactate concentration.

(b) On exercise. Arterial lactate and pyruvate tended to be a little higher than those of normal subjects at the same exercise level (Davies and Gazetopoulos, to be published). The most striking feature, however, was that the most profound hypoxæmia could exist with only a slight increase of arterial lactate, as in Cases 16, 17, and 19. This is surprising in the light of the known association between oxygen lack and lactate production (Hill and Lupton, 1923; Meakins and Long, 1927; Jervell, 1928; Huckabee, 1958). Presumably the fact that the intensity of effort was limited by other factors in severe cases, as will be discussed later, was responsible for the low lactate levels which tended to be lower in the most disabled group (Fig. 5). The peak lactate levels were attained at the point of maximum effort in these patients, and we never saw a late release after the end of exercise.

Pyruvate rose in the usual fashion, the maximum values being reached a few minutes after the end of exercise. The actual levels reached were not remarkable.

Arterial pH. (a) At rest. These were within the upper normal to alkalæmic range, though there was some tendency towards acidæmia in the more hypoxæmic patients (Fig. 6). Of these, Case 16 had a higher than usual resting $\mathrm{P}_{\mathrm{CO}_{2}}$, while Case 19 had a somewhat raised blood lactate. These findings are in keeping with those of Bing et al. (1948) and Morse and Cassels (1953).

(b) On exercise. The arterial $p \mathrm{H}$ fell in all cases except 3 in the acyanotic group. The levels reached were lowest in the most disabled patients. It is of considerable interest that since the lactate levels were low in the latter group, the acidæmia was in the main hypercapnic rather than metabolic in origin. The lowest value seen was 7.24 in Case 18, who had Eisenmenger's complex.

Ventilation. (a) At rest. It has been widely accepted that patients with cyanotic congenital heart disease hyperventilate at rest, in the sense that their minute volume of ventilation is higher than normal. Bing et al. (1948) found that this was so in 29 out of 30 cases, that the arterial $\mathrm{P}_{\mathrm{CO}_{2}}$ and alkaline reserve were reduced, and that the arterial $p \mathrm{H}$ was normal. There appears to be some lack of agreement, however, in the published figures for normal subjects. Baldwin, Cournand, and Richards (1948) and Matheson and Gray (1950) stated that in resting young adults the average ventilation was $4.01 . / \mathrm{min} . / \mathrm{m} .{ }^{2}$, but Bucher (1949) found in 27 cases an average of 6.3 and Shephard (1955) gave the figure as $4 \cdot 2$. Shephard found that the minute ventilation was increased in most forms of congenital heart disease, both in the cyanotic group and in the acyanotic group with increased pulmonary blood flow. Davison et al. (1953) confirmed the resting hyperpnoa of cyanosed patients, though they doubted whether hypoxæmia was the main factor responsible. 


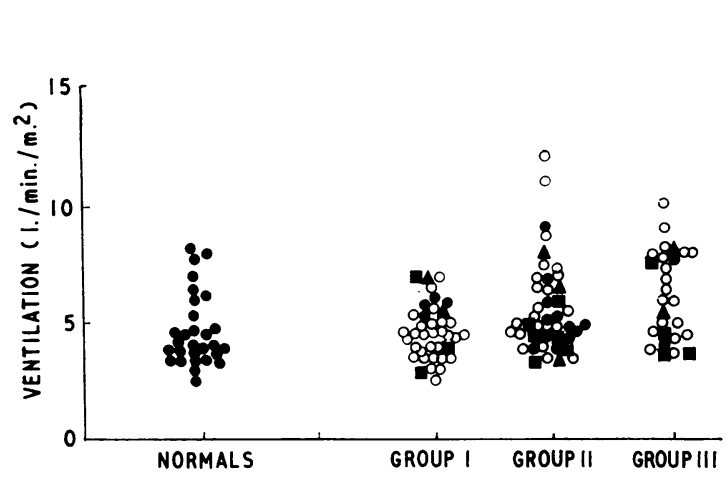

FIG. 7.-The resting ventilation in normal subjects and in three groups of patients with cyanotic congenital heart disease. Open circles represent Fallot's tetralogy; closed symbols Eisenmenger syndrome (circles: ventricular septal defect; squares: atrial septal defect; triangles: patent ductus arteriosus).

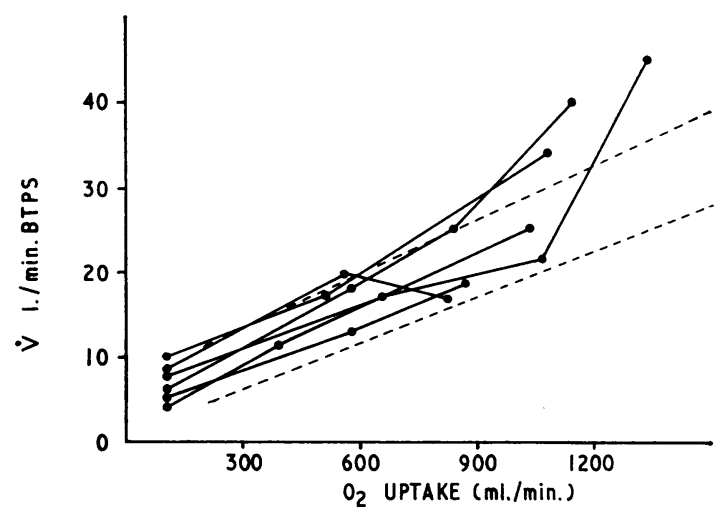

FIG. 8.-The ventilation in relation to the oxygen uptake in six cases of Fallot's tetralogy at rest and on exercise. The dotted lines represent the limits of normality obtained from patients studied in this laboratory and from published cases $(\dot{\mathrm{V}}=$ ventilalation in $1 . / \mathrm{min}$.).

In an attempt to clarify this, we have examined the records of ventilation in a large number of patients during cardiac catheterization. Normal subjects have been compared with cyanosed patients in the Fallot and Eisenmenger groups. Fig. 7 shows the results. It is seen that there is a slightly higher mean level of ventilation in the cyanosed group, but the difference is not significant (mean 4.7 in normals as against 5.5 in the cyanosed patients). The difference between the means in these groups is not significant $(p>0 \cdot 2)$. Here, allowance must also be made for the fact that there is a higher proportion of small people, young and undersized, in the severer groups, the ventilation per square metre being of course greater in smaller subjects (Shock and Soley, 1939; Mannheimer, 1949). In the sedated state, therefore, there is scant evidence of hyperventilation, in the sense of increased minute ventilation, in patients with cyanotic congenital heart disease.

Without sedation the resting ventilation also seems to be within the normal range, though we would not wish to draw firm conclusions from the relatively few measurements that we have at our disposal. We have reservations about accepting the frequently-quoted statements about the resting hyperventilation of cyanotic congenital heart disease, though it is conceivable that under conditions of stress such patients may show an excessive ventilatory response as compared with normal subjects. Patients with the Eisenmenger syndrome are not apparently separated from the Fallot group in respect of their resting ventilation.

(b) On exercise. The first relevant observation is that, as in normal subjects (Åstrand, 1960), the amount of exercise rather than its type is the more important in determining the ventilation. This is well seen in Case 4 (Table III), where the ventilation at similar levels of exercise can be compared, first at catheterization and then during walking; also in Case 17 ventilation while walking and during the lowest level of bicycle exercise is seen to be comparable (leg exercise has always been used during these studies).

A second general observation is that in most cases the ventilatory response is normal up to a certain level of exercise. Above this level the ventilation is greater than expected. With others we use for this the term "relative hyperventilation".

This is seen clearly in patients exercised at more than one level. Fig. 8 shows that in patients with Fallot's tetralogy the relation between ventilation and oxygen consumption is normal at values of $\mathrm{V}_{\mathrm{O}_{2}}$ (oxygen uptake) less than about $800 \mathrm{ml} . / \mathrm{min}$. STPD.* Above this relative hyperventilation occurs. The more severe the cyanosis the lower is this "critical level" (i.e. the level at which relative hyperventilation begins). Generally the acyanotic group was able to attain an

\footnotetext{
* STPD = "standard conditions" for gas volumes $\left(0^{\circ} \mathrm{C} ., 760 \mathrm{~mm} . \mathrm{Hg}\right.$, dry $)$.
} 
exercise level of $400-600$, the intermediate group $300-400$, and the most severe cases less than 300 $\mathrm{kg}$. $\mathrm{m} . / \mathrm{min}$., but there was a notable exception in Case 17 with a functioning Blalock anastomosis which will be discussed later.

The normal ventilatory response of the Fallot group to sub-critical exercise is accompanied by biochemical changes which, oxygen saturation apart, are similar to those in non-cyanosed patients and normal subjects at the same exercise levels. Above the critical level it appears that there are disturbances in the other humoral factors and the level of oxygen tension is not by itself a potent determinant of relative hyperventilation. In Fig. 9 the level of exercise is related to the ventilation and to the measured variables during stepwise increases in exercise in representative cases from each group and one normal subject for comparison. While ventilation is normal up to a certain point, relative hyperventilation begins at lower levels in the patients, according to the severity of the disease as judged by the arterial oxygen saturation at rest.

Oxygen Consumption and Carbon Dioxide Output. (a) At rest. Most authors (Holling and Zak, 1950; Burchell et al., 1950; Ernsting and Shephard, 1951; Davison et al., 1953) have found the basal oxygen consumption to be normal in patients with cyanotic congenital heart disease. Likewise we have seen no abnormality of the oxygen consumption either at cardiac catheterization or before bicycle or step tests. Fig. 10 illustrates the findings in 114 patients and 29 normal subjects drawn from our laboratory records; it is seen that there is no significant difference between the groups.

(b) On exercise. Taking as the basis for comparison the figures of Astrand (1960), we have found no abnormality of the oxygen uptake for a given work load in our patients. Doubtless at higher exercise levels a limit would be imposed by the restriction of pulmonary blood flow, but other factors cause a cessation of exercise before this point is approached. These findings appear to provide further testimony to the fact that adaptive mechanisms are highly effective in preserving the oxygen economy in such cases.

The $\mathrm{CO}_{2}$ output was measured in only a few patients, but in them it was found that at rest and at sub-critical exercise levels the respiratory quotient lay within the normal range. On effort it rises above unity in the patients in whom the arterial $\mathrm{P}_{\mathrm{CO} 2}$ drops, but we have no figures in cases where the latter rises. Our data indicate therefore that the resting oxygen consumption is normal in these patients, and that it increases normally with effort at least up to the critical level of exercise.

Heart Rate. This is higher for a given amount of exercise than in normal subjects (our data), but there are wide individual differences.
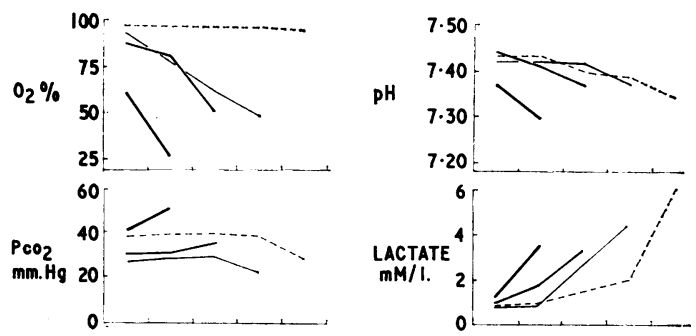

FIG. 9.-Changes in arterial oxygen, $p \mathrm{H}, \mathrm{PCO}_{2}$, lactate, and ventilation measured at different exercise levels in a patient from each of the three groups and a normal subject. The three solid lines, in order of decreasing heaviness, represent Case 16 in Group III, Case 12 in Group II, and Case 4 in Group I.
The broken line represents a normal patient. The intervals on the abscissa in each diagram are as in the lowest one. (Ventilation could not be measured in Case 16.) 
The heart rate cannot be used as an index of exercise limitation or of physical working capacity. Thus in the most severely disabled patient (Case 16) the rate rose no higher than 135 at the point of maximum effort and dyspnœa. This aspect of the circulatory adjustment to exercise is discussed by Kjellberg et al. (1959).

\section{DISCUSSION}

In normal subjects during exercise the ventilation and oxygen uptake increase in linear fashion with the load at lower levels of effort. After a certain point, ventilation increases disproportionately; and at this point there is evidence of lactate accumulation and metabolic acidosis (Dejours, 1959; Cotes, 1963).

Severe effort hyperventilation leads to a fall in $\mathrm{P}_{\mathrm{CO}_{2}}$ to levels that may be well below those of the resting state. The tendency towards alkalæmia, which is the consequence of the release of $\mathrm{CO}_{2}$, only partially compensates for the acidæmia associated with lactate production, and the arterial $p \mathrm{H}$ falls. There are no significant changes in $\mathrm{P}_{\mathrm{O}_{2}}$ of arterial blood of normal subjects on effort (Asmussen and Nielsen, 1958; Mitchell, Sproule, and Chapman, 1958).

Whether or not ventilation is a factor limiting exercise in normal subjects, dyspnœa is usually accompanied by considerable relative hyperventilation, though of course there are wide individual variations in the exercise level needed to produce this, depending on sex, age, body habitus, and state of training.

In normal subjects at the lower levels of exercise, of the order of those to which we have subjected our cyanosed patients, there are biochemical changes of only relatively small degree. The arterial lactate increases to only about $2 \mathrm{mM}$./1., and the $\mathrm{pH}$ and the $\mathrm{P}_{\mathrm{CO}_{2}}$ remain close to their resting values (Dejours, 1959 and our unpublished data). It is against these relatively minor changes that the response of the cyanosed patients must be judged.

In patients who are acyanotic at rest but are cyanosed on effort the metabolic changes with exercise, oxygen saturation apart, are not far removed from normal; the lactate rises to levels a little higher than in normals at the same exercise load, but the increase is not as great as that which we have seen in normal subjects at exercise levels sufficient to produce relative hyperventilation. The "acyanotic" patient has a pulmonary blood flow sufficient to lower the arterial $\mathbf{P}_{\mathrm{CO}_{2}}$ on effort, and hypoxæmia and slight metabolic acidosis appear to be the main humoral disturbances; he can continue exercising without distress in the presence of relative hyperventilation. Thus Case 3, who was almost totally disabled before pulmonary valvotomy and infundibular resection, had a good pulmonary blood flow after operation (Table II). The metabolic changes with effort were small. The main humoral disturbance was hypoxæmia. In Cases 1 and 2, particularly the latter, lactic acidæmia was greater and hypoxæmia relatively mild. It may be significant that they were amongst the older patients, and were unique in this series in that they suffered from angina pectoris.

Where the pulmonary blood flow is adequate, therefore, hyperventilation leads to a fall in arterial $\mathbf{P}_{\mathrm{CO}_{2}}$ to levels below the resting ones. The severely cyanosed patients, on the other hand, show a different pattern of response. On account of the considerably restricted pulmonary blood flow, hyperventilation is ineffectual in clearing the body of carbon dioxide. The changes in lactate are on the whole smaller than those in the acyanotic group for a given degree of disability, and the oxygen saturation is lower. It is of considerable significance that the arterial $\mathbf{P}_{\mathrm{CO}_{2}}$ rises, and that the $p \mathrm{H}$ indicates that there is an acidæmia which is more hypercapnic than metabolic. These facts are fundamental to the understanding of the disability of the cyanosed patients.

The changes in arterial $\mathbf{P}_{\mathrm{CO}_{2}}$ are also of importance in the intermediate group. We have been able to study somewhat more closely the minute-by-minute changes in a few such patients. As shown in Fig. 11 (Case 13), in the first minute of exercise the arterial oxygen fell and the $\mathrm{P}_{\mathrm{CO}_{2}}$ rose as the ventilation increased to its steady-state level. The arterial $p \mathrm{H}$ fell at this stage partly due to the rise in $\mathrm{CO}_{2}$ and partly to the increase of lactate. By the third minute the oxygen had reached a steady level, the $\mathrm{P}_{\mathrm{CO}_{2}}$ was at its first peak, and the $p \mathrm{H}$ was falling in response to the rising lactate. 
In the fifth minute the oxygen was at the same level, but the $\mathrm{P}_{\mathrm{CO}_{2}}$ now fell in response to the hyperventilation. At this stage the ventilation was $31.51 . / \mathrm{min}$. and the oxygen uptake 1.15 1./min. The situation did not then alter materially until at the tenth minute he became dyspnoeic rather suddenly. The oxygen saturation at this time fell again, the $\mathrm{P}_{\mathrm{CO}_{2}}$ rose once more and the $p \mathrm{H}$ fell, the lactate now being unchanged or a little lower than its peak value. It is likely that such changes accompany the sudden access of dyspnœa that is often seen at about this stage of steady exercise.

Thus, of the three classical humoral stimuli to respiration, hypoxia, hypercapnia, and acidæmia, only the latter is present during severe exercise in normal subjects, whereas all three operate in the more disabled cyanosed cases even on mild effort.

Nielsen (1936) and Nielsen and Smith (1952)

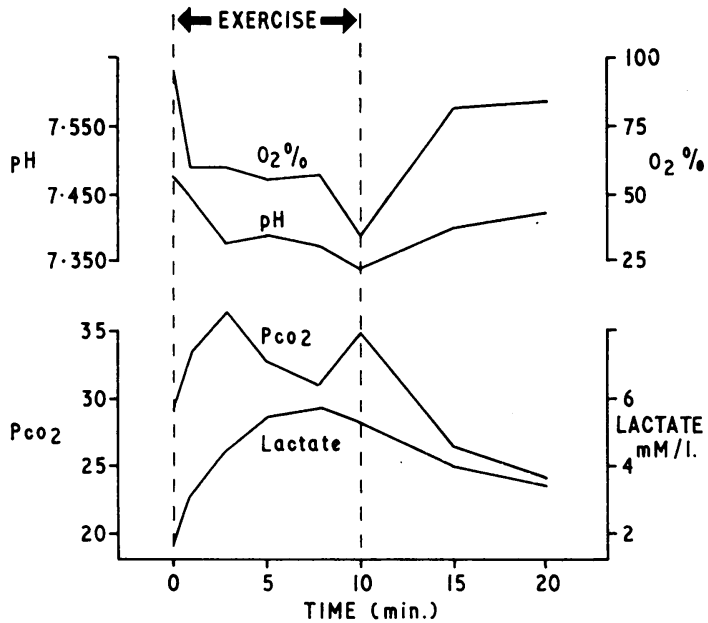

FIG. 11.-The effect of exercise on the arterial oxygen saturation, $p \mathrm{H}, \mathrm{P}_{\mathrm{CO}_{2}}$, and lactate in Case 13 (see text).

showed clearly in normal subjects the interrelation of hypoxia and hypercapnia in the determination of ventilation. At normal alveolar oxygen levels the effect of increasing $\mathrm{P}_{\mathrm{CO}_{2}}$ is apparent above a level of $36 \mathrm{~mm}$. When the alveolar $\mathrm{P}_{\mathrm{O}_{2}}$ is $47 \mathrm{~mm}$., there is little response from increasing $\mathrm{P}_{\mathrm{CO}_{2}}$ until its level reaches $33 \mathrm{~mm}$., after which a further increase of $5 \mathrm{~mm}$. in $\mathrm{P}_{\mathrm{CO} 2}$ leads to a trebling of the ventilation. At a $\mathrm{P}_{\mathrm{O}_{2}}$ of $37 \mathrm{~mm}$. the threshold lies at a $\mathrm{P}_{\mathrm{CO}_{2}}$ of about $31 \mathrm{~mm}$. Thereafter an increase of as little as $2 \mathrm{~mm}$. increases the ventilation by $301 . / \mathrm{min}$. (Nielsen and Smith, 1952).

As Asmussen (1963) points out, the increased response to $\mathrm{CO}_{2}$ under conditions of hypoxia was discussed by Miescher-Rüsch in 1885, and formulated more precisely by Lindhard, in 1911 .

Nielsen (1936) also investigated the influence of acidæmia on ventilation. The lowering of the $\mathrm{CO}_{2}$ threshold following acidæmia caused by ingestion of ammonium chloride was shown clearly. Whether $\mathrm{CO}_{2}$ and acidæmia are separate and cumulative stimuli to respiration is beyond the scope of this paper to discuss, but this concept forms the basis of the multiple-factor theory of Gray (1946) and the later mathematical refinements of the ventilatory equation (e.g. that of Cunningham (1963) and Lloyd (1963)).

Of especial interest was Case 17. This patient with severe Fallot's tetralogy treated by a Blalock anastomosis had a resting arterial oxygen saturation of 76 per cent dropping to 20 per cent with exercise on the bicycle. Despite this gross fall, he was content to carry on at a level of $400 \mathrm{~kg}$. m./min., was not dyspnœic, and was stopped on account of his gross cyanosis. This case illustrates well the measure of adaptation to hypoxæmia, and confirms the view that other factors than this are the special ones related to severe dyspnœa; the arterial $\mathbf{P}_{\mathrm{CO}_{2}}$ did not rise above its resting level, and the $p \mathrm{H}$ dropped only a little by virtue of mild lactic acidæmia.

The general adaptations to hypoxæmia are too well known to require emphasis. On the enzymatic and metabolic levels, adaptation to chronic hypoxia has been shown to exist in animals. Tappan et al. (1957) found that guinea-pigs under those conditions have increased glycolysis and adenosine triphosphatase capacities, and accumulate higher levels of high-energy phosphates. Myoglobin stores, desoxyribonucleic acid, and succinoxidase activity are significantly higher. Hurtado (1963) states that natives of the Andes carry out muscular activity with less production of lactate than sealevel man. Such adaptive mechanisms may be operative in patients with chronic hypoxæmia and the lactate-pyruvate metabolism be correspondingly altered. On the other hand the normal oxygen uptake and the low lactate production of these cases suggests that there is little or no deficiency of oxygen supply to the tissues. 
In 1958 Wood pointed out that in the Eisenmenger syndrome the patient with a patent ductus arteriosus was significantly less disabled than his fellow with a communication at atrial or ventricular level, and gave it as his opinion that this might be due to the fact that the head and neck were supplied with highly oxygenated blood from the left ventricle, the deoxygenated blood entering the aorta through the ductus distal to the origin of the carotid vessels. This observation gains in significance when it is realized that the oxygenated blood, being essentially pulmonary venous in origin, is low in $\mathrm{CO}_{2}$ content. Not only is there differential cyanosis in the patient with the "Eisenmenger ductus", but more significantly to the patient's symptomatology there is "differential hypercapnia".

Miescher-Rüsch in 1885 concluded from his studies that only dissolved carbon dioxide, and not oxygen, was the humoral stimulus to ventilation, though hypoxia could alter the excitability of the respiratory centre. As quoted by Asmussen (1963), he finished his discussion with the sentence, "So carbon dioxide spreads its protecting wings over the oxygen needs of the body." This appears to be particularly appropriate to the patient with morbus cæruleus.

While dyspnœa is a symptom, its objective expression is hyperventilation. Any stimulus to ventilation is, in the appropriate circumstances, a stimulus towards dyspnœa. It is likely that the chemical changes occurring in these cyanosed patients, acting in the milieu of hypoxæmia, are the special ones related to the severe dyspnœa which they suffer.

\section{SUMMARY}

Twenty patients with cyanotic congenital heart disease have been studied at rest and during exercise. All patients showed a fall in arterial oxygen levels on effort, but in those who were acyanotic at rest metabolic changes were slight and arterial $p \mathrm{H}$ and $\mathrm{P}_{\mathrm{CO}_{2}}$ behaved normally. Severely disabled patients who were cyanotic at rest showed on effort a marked rise in arterial $\mathbf{P}_{\mathrm{CO}_{2}}$ and fall in $p \mathrm{H}$ which was in part hypercapnic and in part metabolic. The lactate changes, though greater than normal, were not striking in view of the profound hypoxæmia sometimes present.

The influence of these changes on the ventilatory drive is discussed. It is suggested that, acting in the presence of hypoxæmia, the rise in arterial $\mathrm{P}_{\mathrm{CO}_{2}}$ and the fall in $p \mathrm{H}$ may be the cause of the considerable dyspnœa of the centrally cyanosed patient, and that the magnitude of the pulmonary blood flow, in determining the rate at which carbon dioxide can be cleared from the body, determines also the critical point at which relative hyperventilation and dyspnœa occur.

We wish to thank Dr. C. G. Baker and Dr. D. C. Deuchar for having so readily allowed us to study their patients and put facilities at our disposal for doing so. Dr. M. W. Potts and Mrs. J. R. Samuel of the Department of Anæsthetics have given invaluable assistance with the investigations and the determinations of $p \mathrm{H}$ and $\mathrm{Pco}_{2}$, and to them we are very grateful. The work was supported in part by a grant from Messrs. Boehringer-Ingelheim.

\section{REFERENCES}

Andersen, O. S., and Engel, K. (1960). A new acid-base nomogram. Scand. J. clin. Lab. Invest., $12,177$.

Asmussen, E. (1963). The regulation of respiration. In The Regulation of Human Respiration, ed. D. J. C. Cunningham and B. B. Lloyd, p. 59. Blackwell Scientific Publications, Oxford.

- , and Nielsen, M. (1958). Pulmonary ventilation and effect of oxygen breathing in heavy exercise. Acta physiol. scand., 43, 365.

Åstrand, I. (1960). Aerobic work capacity in men and women, with special reference to age. Acta physiol. scand., 49, Suppl. 169.

Baldwin, E., Cournand, A., and Richards, D. W. (1948). Pulmonary insufficiency. III. A study of 122 cases of chronic pulmonary emphysema. Medicine (Baltimore), 28, 201.

Bing, R. J., Vandam, L. D., Handelsman, J. C., Campbell, J. A., Spencer, R., and Girswold, H. E. (1948). Physiological studies in congenital heart disease. VI. Adaptations to anoxia in congenital heart disease with cyanosis. Bull. Johns Hopk. Hosp., 83, 439.

Bucher, K. (1949). Vergleichende Charakterisierung der Lungenatmung einiger Säuger. Helv. physiol. Pharmacol. Acta, 7, 470 .

Burchell, H. B., Taylor, B. E., Knutson, J. R. B., and Wood, E. H. (1950). Circulatory adjustments to the hypoxemia of congenital heart disease of the cyanotic type. Circulation, 1, 404.

Campbell, J. M. H., Hunt, G. H., and Poulton, E. P. (1923). An examination of the blood gases and respiration in disease, with reference to the cause of breathlessness and cyanosis. J. Path. Bact., $26,234$.

Campbell, M. (1934). The respiratory exchange during exercise in heart disease. Quart.J. Med., 27, 369.

Cotes, J. E. (1963). Exercise limitation in health and disease. Brit. med. Bull., 19, 31. 
Cunningham, D. J. C. (1963). Some quantitative aspects of the regulation of human respiration in exercise. Brit. med. Bull., 19, 25 .

Davies, H., and Gazetopoulos, N. Ventilatory and metabolic response to effort in normal subjects. To be published.

Davison, P. H., Armitage, G. H., and Arnott, W. M. (1953). The mechanisms of adaptation to a central venousarterial shunt. Brit. Heart J., 15, 221.

Dejours, P. (1959). La régulation de la ventilation au cours de l'exercice musculaire chez l'homme. J. Physiol. (Paris), 51, 163.

DuBois, D., and DuBois, E. F. (1915). The measurement of the surface area of man. Arch. intern. Med., 15, 868

Ernsting, J., and Shephard, R. J. (1951). Respiratory adaptations in congenital heart disease. J. Physiol. (Lond.), $112,332$.

Gootman, N. L., Scarpelli, E. M., and Rudolph, A. M. (1963). Metabolic acidosis in children with severe cyanotic congenital heart disease. Pediatrics, 31, 251.

Gray, J. S. (1946). The multiple factor theory of the control of respiratory ventilation. Science, 103, 739.

Hallock, P. (1939). Lactic acid production during rest and after exercise in subjects with various types of heart disease with special reference to congenital heart disease. J. clin. Invest., 18, 385.

Havel, R. J., and Watkins, E. (1950). The metabolism of lactate and pyruvate in children with congenital heart disease. Circulation, 2, 536.

Hill, A. V., and Lupton, H. (1923). Muscular exercise, lactic acid, and the supply and utilization of oxygen. Quart. J. Med., 16, 135.

Holling, H. E., and Zak, G. A. (1950). Cardiac catheterization in the diagnosis of congenital heart disease. Brit. Heart $J ., 12,153$.

Huckabee, W. E. (1958). Relationships of pyruvate and lactate during anærobic metabolism. II. Exercise and formation of $\mathrm{O}_{2}$-debt. J. clin. Invest., 37, 255.

Hugh-Jones, P., and Lambert, A. V. (1952). A simple standard exercise test and its use for measuring exertion dyspnœa. Brit. med. J., 1, 65.

Hurtado, A. (1963). Natural acclimatization to high altitudes. In The Regulation of Human Respiration, ed. D. J. C. Cunningham and B. B. Lloyd, p. 71. Blackwell, Oxford.

Jervell, $O$. (1928). Investigation of the concentration of lactic acid in blood and urine under physiologic and pathologic conditions. Acta. med. scand., Suppl. 24.

Kjellberg, S. R., Mannheimer, E., Rudhe, U., and Jonsson, B. (1959). Diagnosis of Congenital Heart Disease, 2nd ed. Year Book Publishers, Chicago.

Landon, J., Fawcett, J. K., and Wynn, V. (1962). Blood pyruvate concentration measured by a specific method in control subjects. J. clin. Path., 15, 579.

Lindhard, J. (1911). On the excitability of the respiratory centre. J. Physiol. (Lond.), 42, 337.

Lloyd, B. B. (1963). The chemical stimulus to breathing. Brit. med. Bull., 19, 10.

Mannheimer, E. (1949). Morbus Caeruleus. S. Karger, Basel.

Matell, G. (1963). Time-courses of changes in ventilation and arterial gas tensions in man induced by moderate exercise. Acta physiol. scand., 58, Suppl. 206.

Matheson, H. W., and Gray, J. S. (1950). Ventilatory function tests. III. Resting ventilation, metabolism, and derived measures. J. clin. Invest., 29, 688.

Meakins, J., and Long, C. N. H. (1927). Oxygen consumption, oxygen debt and lactic acid in circulatory failure. J. clin. Invest., 4, 273.

Miescher-Rüsch, F. (1885). Bemerkungen zur Lehre von den Athembewegungen. Arch. Physiol. (Lpz.), p. 355.

Mitchell, J. H., Sproule, B. J., and Chapman, C. B. (1958). Factors influencing respiration during heavy exercise. J. clin. Invest., 37, 1693.

Morse, M., and Cassels, D. E. (1953). Arterial blood gases and acid-base balance in cyanotic congenital heart disease. J. clin. Invest., 32, 837.

New York Heart Association (1953). Nomenclature and Criteria for Diagnosis of Diseases of the Heart and Blood Vessels, 5th ed. New York.

Nielsen, M. (1936). Untersuchungen über die Atemregulation beim Menschen. Skand. Arch. Physiol., 74, Suppl. 10 , p. 83.

- and Smith, H. (1952). Studies on the regulation of respiration in acute hypoxia. Acta physiol. scand., 24, 293.

Rahn, H., and Otis, A. B. (1949). Continuous analysis of alveolar gas composition during work, hyperpnea, hypercapnia, and anoxia. J. appl. Physiol., 1, 717.

Scholz, R., Schmitz, H., Bücher, T., and Lampen, J. O. (1959). Über die Wirkung von Nystatin auf Bäckerhefe. capnia, and anoxia. Biochem. Z., 331, 71 .

Severinghaus, J. W. (1958). In Handbook of Respiration, ed. D. S. Dittmer and R. M. Grebe, p. 73. Saunders, Philadelphia.

Shephard, R. J. (1955). The resting hyperventilation of congenital heart disease. Brit. Heart J., 17, 153.

Shock, N. W., and Soley, M. H. (1939). Average values for basal respiratory functions in adolescents and adults. J. Nutr., 18, 143.

Suskind, M., Bruce, R. A., McDowell, M. E., Yu, P. N. G., and Lovejoy, F. W. (1950). Normal variations in end-tidal arterial blood carbon dioxide and oxygen tensions during moderate exercise. J. appl. Physiol., 3, 282.

Tappan, D. V., Reynafarje, B., Potter, V.O., and Hurtado, A. (1957). Alterations in enzymes and metabolites resulting from adaptation to low oxygen tensions. Amer. J. Physiol., 190, 93 .

Wood, P. (1958). The Eisenmenger Syndrome; or pulmonary hypertension with reversed central shunt. Brit. med. J., 2.701. 